\title{
PHYSICAL, MECHANICAL AND THERMAL BEHAVIOUR OF ADOBE STABILIZED WITH THE SLUDGE OF WASTEWATER TREATMENT PLANTS
}

\author{
Rômulo M. Gandia ${ }^{1 *}$, Francisco C. Gomes ${ }^{2}$, Andréa A. R. Corrêa ${ }^{2}$, Maykmiller C. Rodrigues², \\ Diego B. Marin ${ }^{2}$
}

\author{
${ }^{1 *}$ Corresponding author. Federal University of Lavras/ Lavras - MG, Brazil. \\ E-mail: romagandia@gmail.com | ORCID ID: https://orcid.org/0000-0002-7786-1525
}

KEYWORDS
wastewater treatment
plants, building
materials,
sustainability,
composite materials,
waste in construction.

\begin{abstract}
The need for treated water is essential for life. With the constant increase in population, the most common way to purify surface water is through conventional water treatment plants (WTPs). The high volume of residue (sludge) generated in this process is most often returned to the catchment site, negatively affecting the ecosystem. The sludge of WTPs is similar to soil because it is composed of inorganic solids. Adobe is a construction material made from water and soil without the burning process, so it is considered sustainable, recyclable, and energy-efficient and can be stabilized with various materials. Therefore, the objective of this work is to develop adobes using the sludge of WTPs and to analyse their physical, mechanical and thermal properties. Adobes were produced with five concentrations of sludge by mass: $0,1,3,5$ and $7 \%$. It was observed that with the increase in the sludge concentration, there was an increase in the capillarity and a decrease in mass, the water absorption was limited to $3 \%$ of sludge, and there was an increase in the bulk density. The linear shrinkage, thermal conductivity and compressive strength were not influenced. The addition of WTP sludge altered some properties of adobe. The use of WTP sludge in adobe is limited to 3\%; above that, the adobe becomes unstable in relation to water. Therefore, the use of WTP sludge in the manufacture of adobe is feasible in controlled concentrations and is a sustainable use of the residue.
\end{abstract}

\section{INTRODUCTION}

Growing environmental concerns have led to the search for solutions to minimize and direct the generation of waste, reducing excessive energy expenditure and the constant extraction of natural resources.

Adobe is a material that does not sinter and does not use cement; it is composed of only soil and water, and when feasible and necessary, stabilizers can be added. Adobe is a clay material. It does not burn and only dries by air. Moreover, it is considered a recyclable, renewable and sustainable material (Galán-Marín et al., 2010), with low energy costs (Gandia et al., 2018), low thermal conductivity (Balkis, 2017; Palme et al., 2014), low water demand (Corrêa et al., 2006), low cost and easy application in construction (Pacheco-Torgal \& Jalali, 2012) relative to conventional building materials and methods.

The field of study in adobe is broad and growing. Among the challenges, adobe presents low compressive strength and high water absorption. Researchers analyse various stabilizers (some as a form of waste) to improve such properties of adobe (Millogo et al., 2014; Corrêa et al., 2015; Danso et al., 2015; Aguilar et al., 2016; Dove et al., 2016; Hamard et al., 2016; Laborel-Préneron et al., 2016; Millogo et al., 2016; Stazi et al., 2016; Eires et al., 2017; Nakamatsu et al., 2017; Gandia et al., 2019).

The sludge from water treatment plants (WTPs) has become a study target due to the high volume generated and the fact that most of it is incorrectly disposed of (Di Bernardo et al., 2012), leading to environmental problems. WTP sludge is classified as a solid waste and must be handled and disposed of as required by regulatory agencies (ABNT, 2004a; ABNT, 2004b). In Brazil, 17,000 tons of sludge per year are generated from 162 WTPs (Sanepar, 2014). Fonollosa et al. (2015) defined WTP sludge as organic and inorganic solids, including heavy metals, depending on the composition of the raw water.

The average proportion of sludge generated in a WTP varies greatly, according to Richter (2001). This proportion is 0.2 to $5 \%$ of the volume of treated water, and according to Ferreira Filho \& Waelkens (2009), 10 to 60

\footnotetext{
${ }^{2}$ Federal University of Lavras/ Lavras, Brazil.

Received in: 2-15-2019

Accepted in: 6-15-2019
} 
grams of sludge per $\mathrm{m}^{3}$ of treated water are generated. The management of WTP sludge disposal requires careful analysis and is a challenging task (Ahmad et al., 2016).

In recent years, several studies have evaluated an alternative for WTP sludge disposal. Hoppen et al. (2006) replaced cement and aggregates with sludge in concrete structures. Teixeira et al. (2011) used sludge from the decantation tank in ceramic materials. Martínez-García et al. (2012) replaced clay with sludge in ceramic bricks. Tao et al. (2012) evaluated the germinative power in plants with the use of sludge. Huang \& Wang (2013) used sludge in the production of light aggregate. Kizinievič et al. (2013) incorporated sludge ash in ceramic materials. Rodrigues \& Holanda (2013) used sludge in soil-cement production. Gastaldini et al. (2015) replaced cement with sludge ash in concrete production. González-Corrochano et al. (2016) produced light aggregates based on sludge. Lucena et al. (2016) incorporated sludge into the paving. Tafarel et al. (2016) and Ramirez et al. (2017) replaced sand with sludge in concrete production. However, there was no evidence of adobe production using WTP sludge.

With the purpose of associating sustainability to engineering, the objective is the production and evaluation of adobes using WTP sludge from the Federal University of Lavras (UFLA), and verification of their physical, mechanical and thermal properties.

\section{MATERIAL AND METHODS}

The adobes were produced with different amounts of WTP sludge. The soil and sludge characterizations were performed before production. The treatments were Control, $\mathrm{S} 1, \mathrm{~S} 3, \mathrm{~S} 5$ and $\mathrm{S} 7$ corresponding to $0,1,3,5$ and $7 \%$ mass, respectively, of WTP residue in the adobe. All of them were made in the same period, dried for 35 days under protection from the sun and weathering, and using the same dimensions of shapes $(30 \times 15 \times 8 \mathrm{~cm})$.

The samples of adobes were examined for 7 properties in the physical, mechanical and thermal tests. The properties examined in the physical tests were bulk density, linear shrinkage, water absorption and capillarity. The property examined in the mechanical tests was compressive strength, and 2 methodologies were compared. The property examined in the thermal test was thermal conductivity.

\section{Materials characterization}

The soil belonged to B horizon with a depth of 1.3 $\mathrm{m}$, was free of organic matter and was located on the campus of the Federal University of Lavras. It is classified as Red Latosol (Embrapa, 2013) with a very clayey texture $\left(600 \mathrm{~g} \mathrm{~kg}^{-1}\right)$. The soil was corrected with $600 \mathrm{~kg}$ of average sand for every $1000 \mathrm{~kg}$ of soil in natura.

The sludge was collected at the WTP Station of the Federal University of Lavras (UFLA) with a monthly average volume of 15,286.84 $\mathrm{m}^{3}$ of treated water (Rodrigues, 2015). The sludge was collected by the decanter and the filters every 15 days for two months. The characterization of the material was done after drying and crushing.

WTP sludge is similar to soil (AWWA, 1996), so the characterization was done using the same analysis for both. After collecting, separating and processing, both analyses were performed. The analyses were: grain size curve, texture, limits of consistency, specific mass, chemical composition and X-ray diffraction of the mineral clay part. Table 1 shows the characteristics of the soil in natura and soil corrected with sand and WTP sludge.

TABLE 1. Properties of soil and soil corrected with sand and sludge of WTPs.

\begin{tabular}{ccccc}
\hline & Soil in natura & Soil corrected (soil+sand) & Sludge & Method \\
\hline Organic matter (\%) & 1 & 1 & 3 & NBR 7181/84 \\
Clay (\%) & 65 & 41 & 57 & \\
Silt (\%) & 6 & 2 & 17 & NBR 6459/04 \\
Sand (\%) & 28 & 56 & 23 & NBR 7180/81 \\
LL (\%) & 40.0 & 27.0 & 59.41 & NBR 7183, adapted \\
PL (\%) & 29.8 & 20.3 & 44.49 & 39.47 \\
LC (\%) & 16.8 & 19.0 & 2.48 & NBR 9776/DNER-ME 093/94 \\
\hline
\end{tabular}

LL: liquid limit, PL: plastic limit, LC: limit of contraction.

Table 1 highlights several factors: the greater the presence of organic matter in the sludge; the higher the concentration of sand after soil correction and the subsequent increase in the specific mass and lower index of plastic (LL-LP); and consequently, a lower range of soil moisture to achieve soil workability. The average size of the materials, including the sand used for soil correction, is shown in Figure 1. 


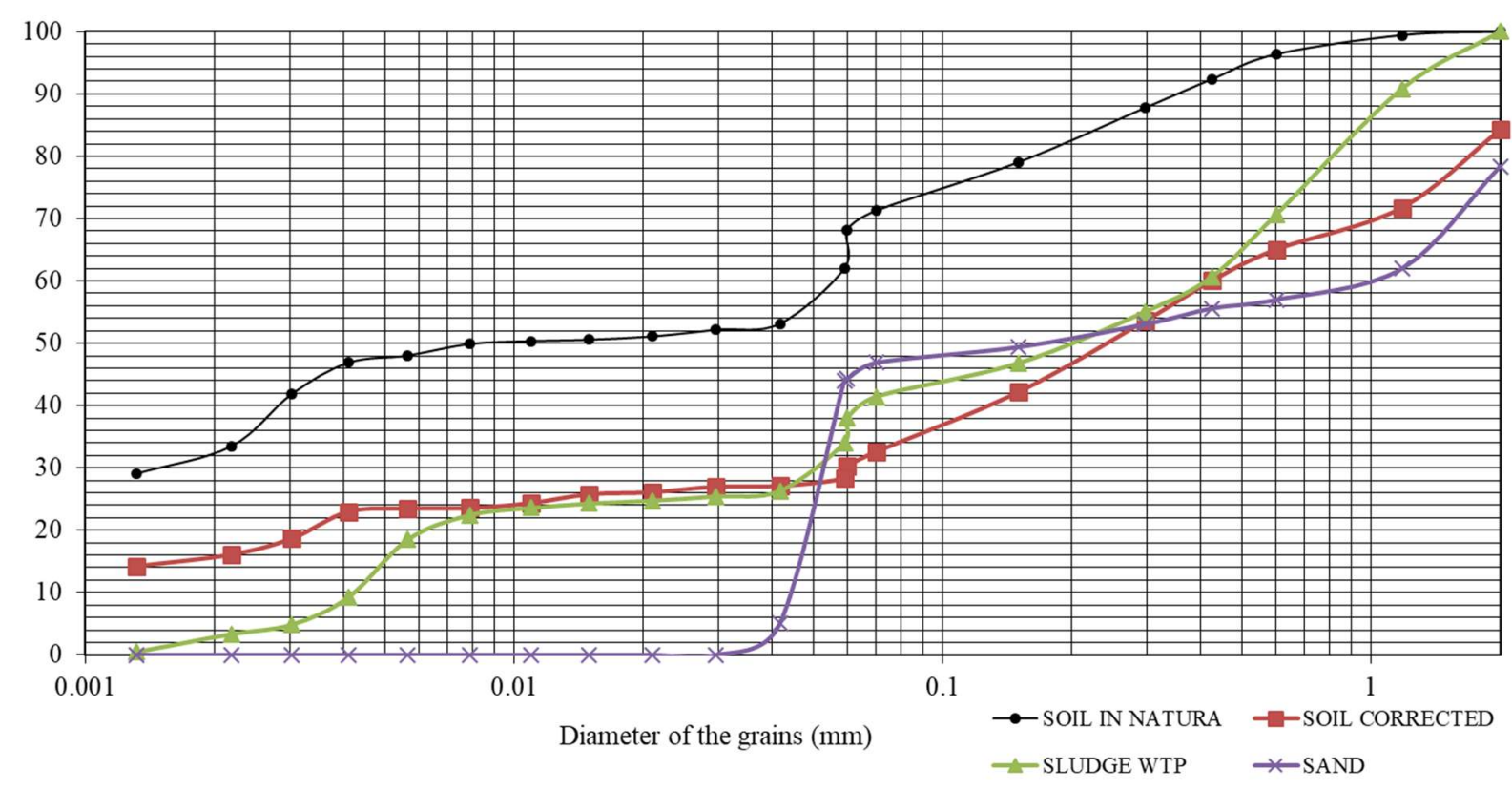

FIGURE 1. Granulometric curve for the soil in natura and soil corrected with sand and WTP sludge.

The purpose of drying and processing the sludge was to achieve a greater homogenization of the composite between the soil and sludge. In this way, it is possible to observe in Figure 1 that after correction of the soil with the sand (red curve) and the processed sludge (green curve), there is a great similarity between the grain size curves, possibly occurring from the effect of packaging, thus obtaining adobes with better properties. The greater specific mass of the sludge in relation to the soil (shown in Table 1) is explained by the greater presence of iron oxide (Table 2). The chemical composition by X-ray fluorescence of the materials is shown in Table 2.

TABLE 2. Chemical composition of the materials.

\begin{tabular}{lccc}
\hline \multicolumn{1}{c}{ Oxide content } & \multicolumn{2}{c}{ Concentration (\%) } \\
& Soil in natura & Soil corrected & Sludge WTP \\
\hline $\mathrm{SiO}_{2}$ (silicon dioxide) & 21.28 & 25.46 & 17.23 \\
$\mathrm{Al}_{2} \mathrm{O}_{3}$ (aluminum oxide) & 21.96 & 23.27 & 12.99 \\
$\mathrm{Fe}_{2} \mathrm{O}_{3}$ (iron oxide) & 8.49 & 7.14 & 22.83 \\
$\mathrm{MgO}$ (magnesium oxide) & 3.60 & 3.36 & 5.80 \\
$\mathrm{MnO}$ (manganese oxide) & 0.04 & 0.03 & 0.19 \\
$\mathrm{TiO}_{2}$ (titanium dioxide) & 1.12 & 1.02 & 0.55 \\
$\mathrm{~K}_{2} \mathrm{O}$ (potassium oxide) & 0.14 & 0.31 & 0.18 \\
$\mathrm{CaO}$ (calcium oxide) & 0.05 & 0.37 & 0.34 \\
$\mathrm{P}_{2} \mathrm{O}_{5}$ (phosphorus petoxide) & 0.07 & 0.13 & 0.07 \\
\hline
\end{tabular}

The sludge fraction presented a high iron oxide content, in part due to the added flocculating reagent during the wastewater treatment. The increased presence of magnesium oxide was probably caused by sediment from the urban sewage system. A great similarity between the soils was observed, and a considerably higher concentration of silicon dioxide in the soil corrected with sand was due to the addition of pure sand. The sludge presents a composition similar to that of the soils, indicating the similarity of the soil that composes the surroundings of the lagoon, i.e., the place of abstraction of water, but presents a clay with an amorphous structure, as indicated in Figure 2. 

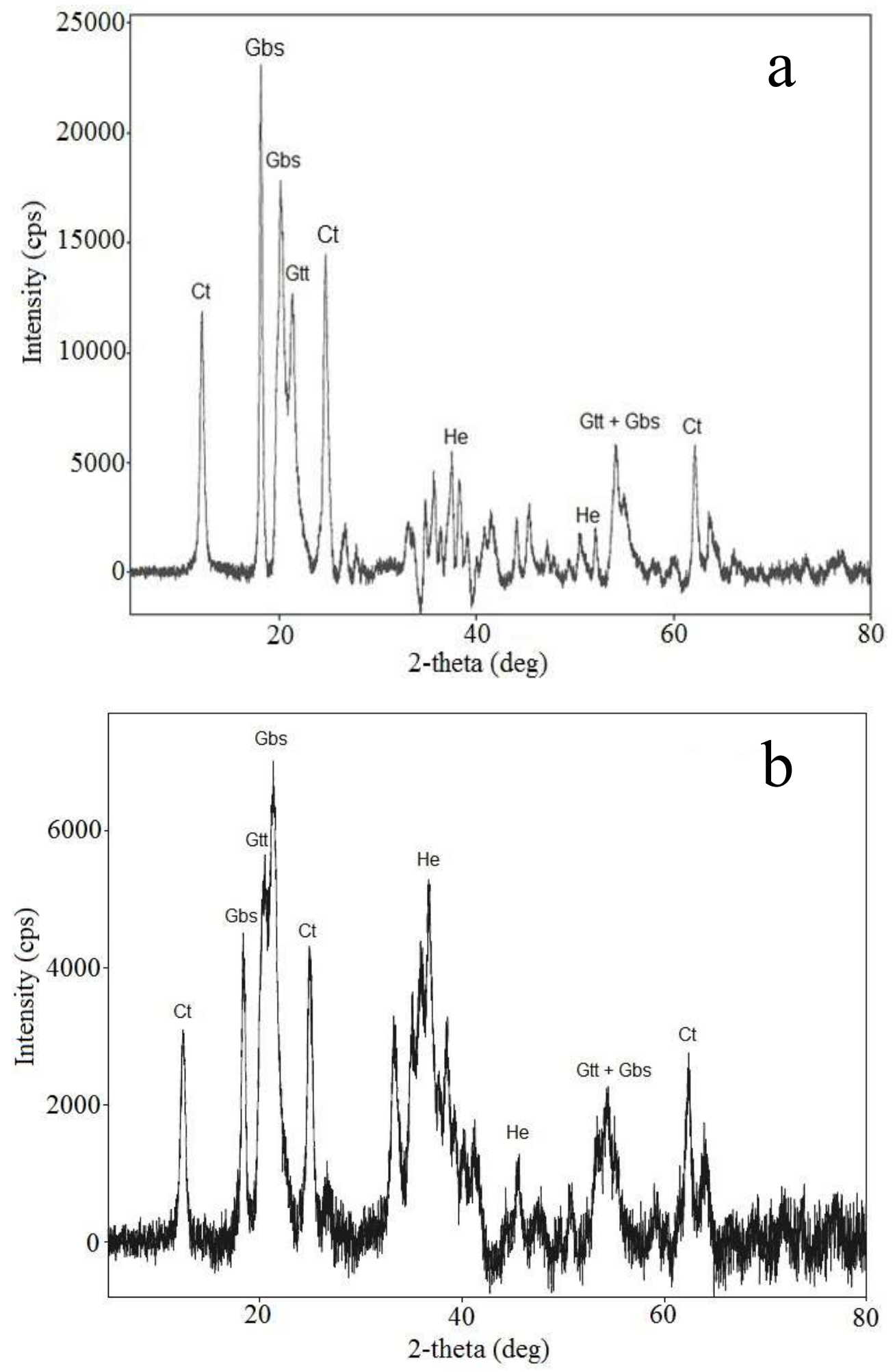

FIGURE 2. Diffractogram of the samples: Soil in natura (a) and WTP sludge (b) of the clay fraction. $\mathrm{Ct}$ (kaolinite), Gbs (gibsite), Gtt (goethite) and He (hematite).

The soil X-ray diffraction (Figure 2a) of the clay fraction identified the presence of kaolinite - Ct (1-1), which has strong bonds and prevents the adsorption of water, without significant expansion when in contact with water, and features a highly crystalline, therefore stable structure.
The XRD test of the WTP sludge (Figure 2b) also showed the presence of kaolinite - Ct (1-1), but with the presence of amorphous materials, without stability, and is able to expand when in contact with water. The whole process of collection and preparation of the sludge is presented in Figure 3. 


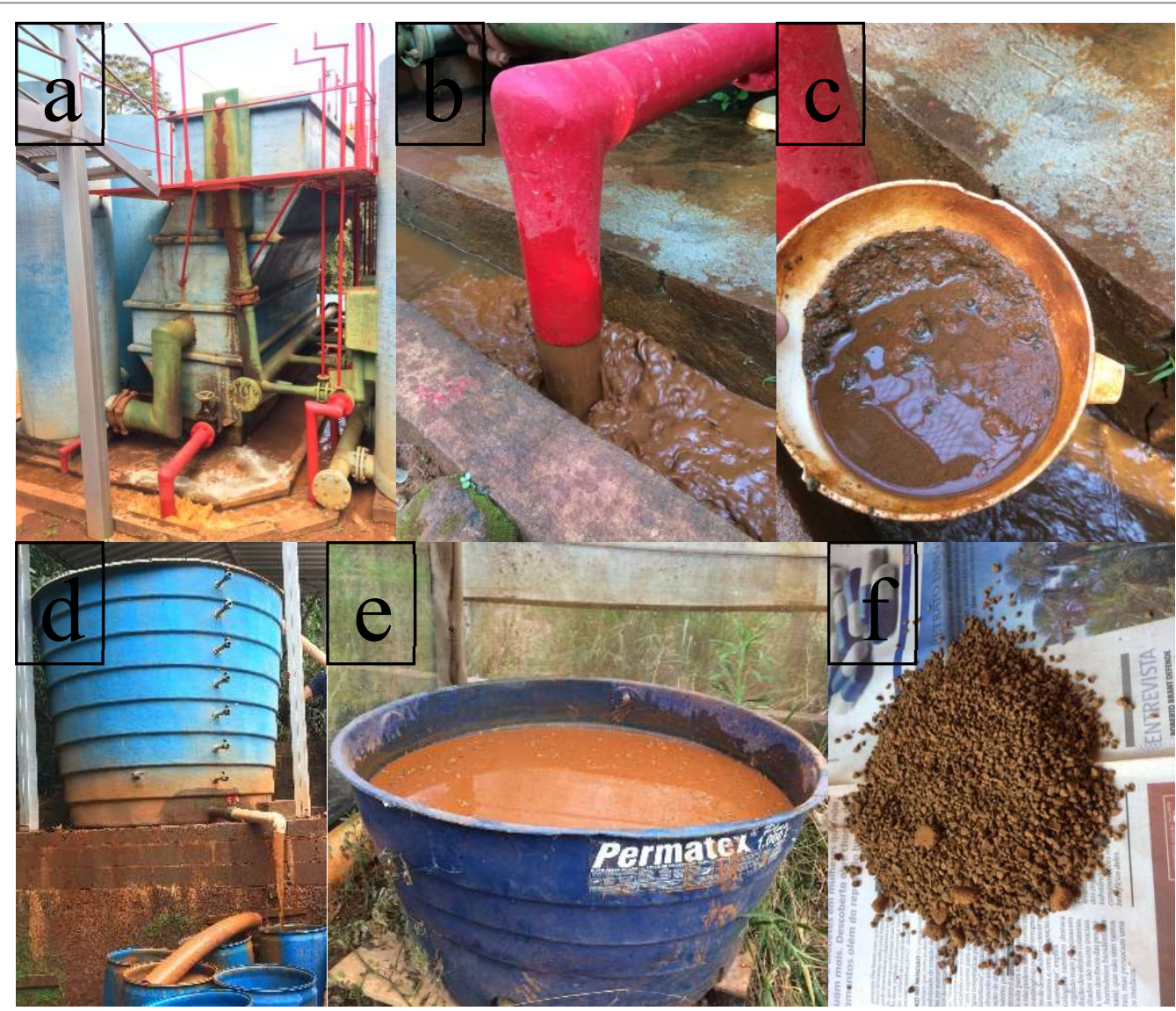

FIGURE 3. Collection and processing of WTP sludge.

WTP of UFLA (a), sludge collected by decanter (b), sludge sample before sedimentation (c), settling box (d), drainage box and drying (e), dry sludge before grinding (f).

The sludge in its state with a higher concentration of water was collected directly in the WTP. By gravity, the same sludge was carried to the sedimentation box (Lima \& Tavares, 2008), and stored for 2 days. The sludge, with a lower concentration of water, was taken to two drainage boxes (Rodrigues, 2015) and dried for 25 days to transform into a solid state, presenting a humidity of approximately $4 \%$ (similar to soil). After the sludge drying process, it was crushed to provide a similar particle size of soil granulometry.

\section{Experimental plan and production}

The adobes were manufactured in the same period, with drying for 35 days and protection from the sun and weathering. The dimension of the form for manufacturing was $30 \times 15 \times 8 \mathrm{~cm}$. Five treatments were produced and analysed: 0 (control), 1.0 (S1), 3.0 (S3), 5.0 (S5) and 7.0\% (S7) of WTP sludge in mass. As the use of ETA sludge in adobe is scarce, therefore the choice of percentages of additions was due to the research with the residue in ceramic and cement materials that, although presenting different behaviours, limited the use of the residue in the composites.
The drying period is variable. Several studies have used 14 to 42 days. In this work, 35 days was used, being the ideal period for the stabilization of adobe humidity (approximately $2 \%$ of water). To reach this time, a mass and volume measurement was done at weekly frequency.

The production (Figure 4) was done with the soil corrected with sand, water and the WTP sludge. Before the production of each treatment, the moisture content was obtained from the 3 soil and sludge samples by the oven method at $103 \pm 2{ }^{\circ} \mathrm{C}$. The amount of water added in the production varied between the liquid limit and the plastic limit of the soil and the sludge. To determine the ideal moisture and consistency, two empirical tests were performed (Figure 4), i.e., "Fall of the Ball" (Barbosa \& Ghavami, 2007) and "Vicat Test" (Ruiz \& Luna, 1983). These were measured by the oven method at $103 \pm 2{ }^{\circ} \mathrm{C}$ in 3 samples of the mass of the adobe, using an oven for 24 hours. A good quality adobe must be homogenized, so the production had 3 stages: manual mixing with shovels and hoes, trampling and homogenization in a "maromba". 


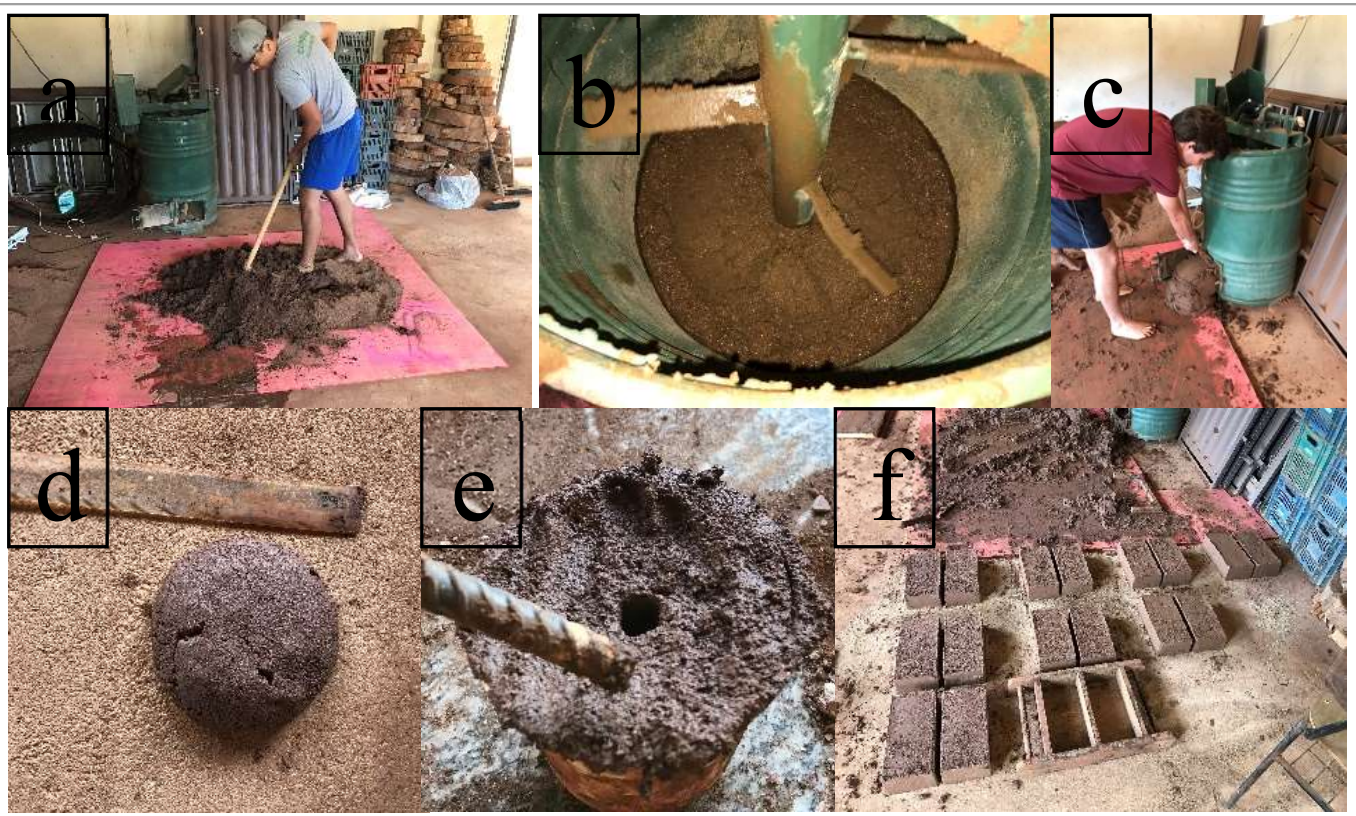

FIGURE 4. Production steps and humidity tests.

Corrected soil + WTP sludge, mixed by shovel and stepping (a), homogenization by a "maromba" (b), homogenized adobe mass (c), "ball drop" test (d), Vicat test (e) and shaped adobe (f).

\section{Tests}

\section{Physical}

The bulk density test was done with 5 randomly chosen adobes after 35 days of drying. Ten measurements were made: 4 in height, 2 in length, and 4 in width using a $30 \mathrm{~cm}$ digital calliper. The mean of each dimension was calculated by [eq. (1)]. The mass was found using a digital scale in grams:

$$
d=\frac{m}{v}
$$

Where:

$$
\begin{aligned}
& \mathrm{d} \text { - bulk density }\left(\mathrm{g} \cdot \mathrm{cm}^{-3}\right) \\
& \mathrm{m} \text { - adobe mass }(\mathrm{g}), \\
& \mathrm{v} \text { - volume }\left(\mathrm{cm}^{3}\right) .
\end{aligned}
$$

For the linear shrinkage test, a box proposed by Faria (2002) adapted with known dimensions was prepared for 6 samples with a dimension of $60 \times 8.5 \times 3.5 \mathrm{~cm}$. The test was done in triplicate. The boxes were filled with the mass used to produce the adobe, smoothing the surface to level and adjusting each sample. After a period of 7 days, the linear retraction of each treatment was measured. The retraction cannot exceed $20 \mathrm{~mm}$ for bricks and soil-cement blocks according to BNH (1985).

The water absorption and mass loss test was performed according to the modified methodology of Varum et al. (2007). For each treatment, 5 samples of adobes were cut in half after drying. In a box of $60 \times 35 \times$ $10 \mathrm{~cm}$, the previously weighed samples were placed, and the box was filled with water (17 litres) until the samples were submerged. After 6 hours, the samples were weighed again to obtain the amount of water absorbed. The soil material deposited in the boxes was collected and oven dried to calculate the mass loss by [eq. (2)]:

$$
\mathrm{Mdp}=\mathrm{Mbdp}-\mathrm{Mb}
$$

Where:

$$
\begin{aligned}
& \text { Mdp - Mass of deposited material (g); } \\
& \text { Mbdp - Mass of box and deposited material (g), } \\
& \text { Mb - Mass of empty box (g). }
\end{aligned}
$$

The capillary test was conducted following the model of Varum et al. (2007). For each treatment, 5 adobes were used and placed in a plastic container. An amount of water of known height of $1.4 \mathrm{~cm}$ was added. After one hour, four measurements of the height of absorbed water were made: two in width and two in length. The material deposited in the containers was collected and oven dried to calculate the mass loss by equation (2).

\section{Compressive strength}

Two compressive strength tests were performed: one according to NTE. E.080 (NTE, 2000), by cutting the adobe in half and using a mortar between them and at both extremities for levelling, and the other according to the Brazilian standard (in the process of approval, study committee CE-02: 123.09, ABNT / CB-02), by cutting the adobe in 8 equal parts and using the two central and diagonal cut samples and using only the levelling mortar at both extremities. Figure 5 shows the line of cuts of both standards. Therefore, 2 sample preparation variables were analysed for the compressive strength test (Figure 5): NTE E. 080 and Brazilian standard. 


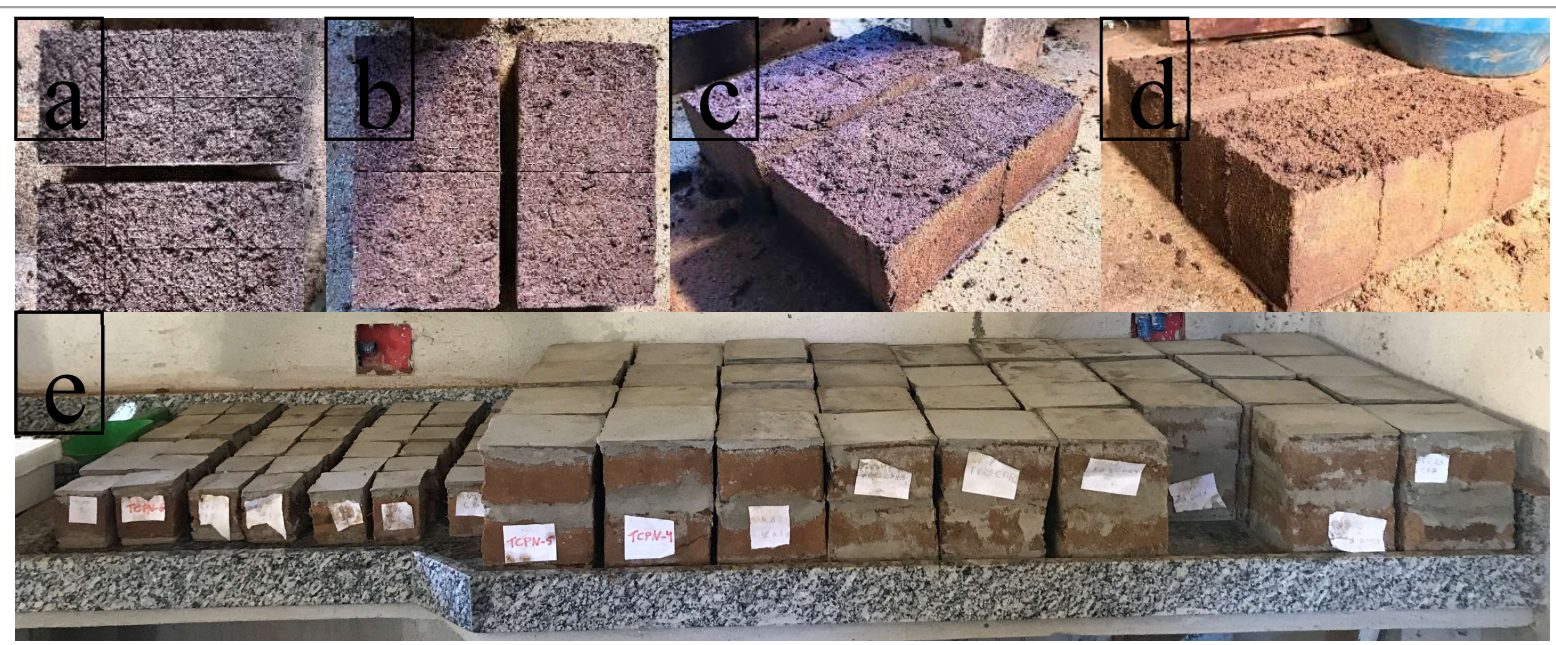

FIGURE 5. Preparation of adobes for the compressive test according to NTE E 080 and Brazilian standard.

Superior view of the adobes cut by the Brazilian standard (a), superior view of the adobes cut by NTE.E-080 (b), lateral view of the adobes cut by NTE.E-080 (c), lateral view of the adobes cut by the Brazilian standard (d), adobes capped and ready for testing (e).

\section{Thermal conductivity}

The thermal conductivity assay was performed in a chamber developed by MDP (Medium Density Particleboard) of cane bagasse. The chamber has two layers of coatings, namely, Styrofoam and thermal blanket, in order to isolate the external medium. The lower part has a heat source (incandescent lamp) connected to a thermostat maintaining the temperature at $47.0^{\circ} \mathrm{C}$. The system has 4 thermocouples: the lamp temperature controller, the ambient temperature, the temperature before entering the sample and the temperature after exiting the sample. The entire system is connected to an Arduino. To validate the system, verification of the heat output (Figure 8) was made with an infrared sensor camera (Fluke TI55FT20 / 54 / 7.5) with an accuracy of $\pm 0.05^{\circ} \mathrm{C}$.

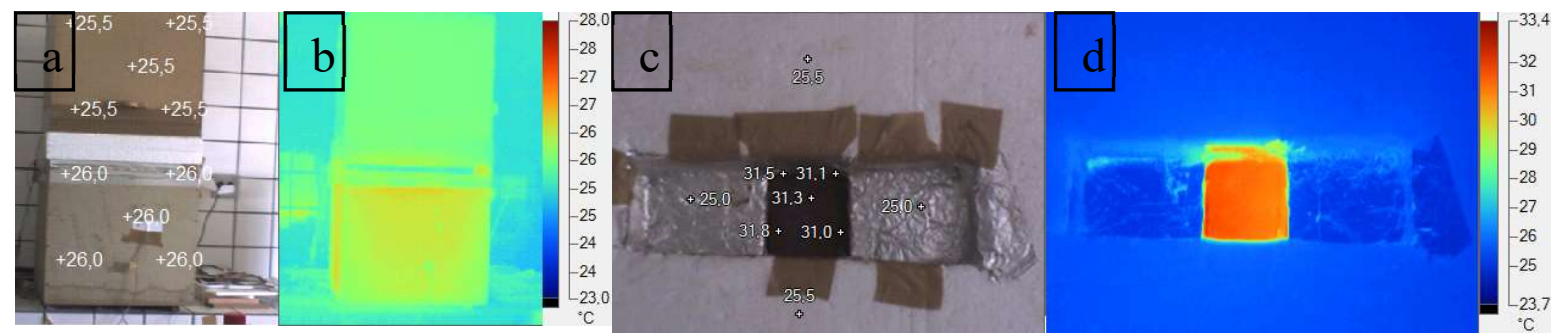

FIGURE 6. External and upper views of the thermal box and its thermographic images.

External view of the camera with point temperatures (a). Infrared image of the thermal box and temperature chart (b). Sample location and point temperatures, showing that there is heat insulation (c). Thermographic image of the thermal box and temperature scale (d).

The samples for the thermal assay were taken from the retraction box test after 35 days. The sample sizes are $7 \times 7.5$ in length and width with a variable height for each sample, varying between 2.78 and $2.96 \mathrm{~cm}$ depending on the retraction that each addition had. The sampling time was pre-determined as 3.33 hours, referring to 1000 readings of 12 seconds each. Five replicates were made per treatment, and the value of the intermediate sample was used.

For calculating the thermal conductivity, the following equation was used, proposed by Silva (2010):

$$
K=P . E / \Delta T
$$

Where:

$$
\begin{aligned}
& \mathrm{K} \text { - thermal conductivity, } \mathrm{W}\left(\mathrm{mC}^{\mathrm{o}}\right)^{-1} \text {; } \\
& \mathrm{P} \text { - radiation of the incandescent lamp, } \mathrm{W} \mathrm{m}^{-2} \text {; } \\
& \mathrm{E} \text { - thickness of the sample, } \mathrm{m} \text {, and } \\
& \Delta T \text { - temperature difference to stabilization }\left(\mathrm{C}^{\mathrm{o}}\right) \text {. }
\end{aligned}
$$

The radiation of the lamp was obtained by a solar radiation metre (Intrutherm model MES-100). Five samples were collected, and the mean value calculated was 207.34 $\mathrm{W} \mathrm{m}^{-2}$. The temperature variation $(\Delta \mathrm{T})$ was collected during the sampling of 3.33 hours.

\section{Microstructure}

Microstructural visualization was done using a SMZ 1500 epi-fluorescence (Nikon) stereoscope microscope and a scanning electron microscope (SEM) (model LEO EVO 40 XVP). The samples used were from the adobe fragments after the compressive strength test for visualization and interpretation of the interaction between the matrix (soil) and the fibres (GFRP residue).

\section{Statistical analysis}

Statistical analysis was performed partially by Sisvar software version 5.6 (Ferreira, 2011). Statistical analysis of each physical and thermal test was done in a single 
completely randomized design. The Tukey test was used to analyse the significant difference at 5\%. For the compressive strength test, a completely randomized design was used in a 5:2 factorial system, in which 5 were the addition concentrations and 2 were the methodologies tested.

\section{RESULTS AND DISCUSSION}

The microstructural analysis of the adobe with and without sludge after the compression test presented in Figure 7 gives us some assumptions such as the pore number, structural homogenization of the clay and cohesion of the particles.
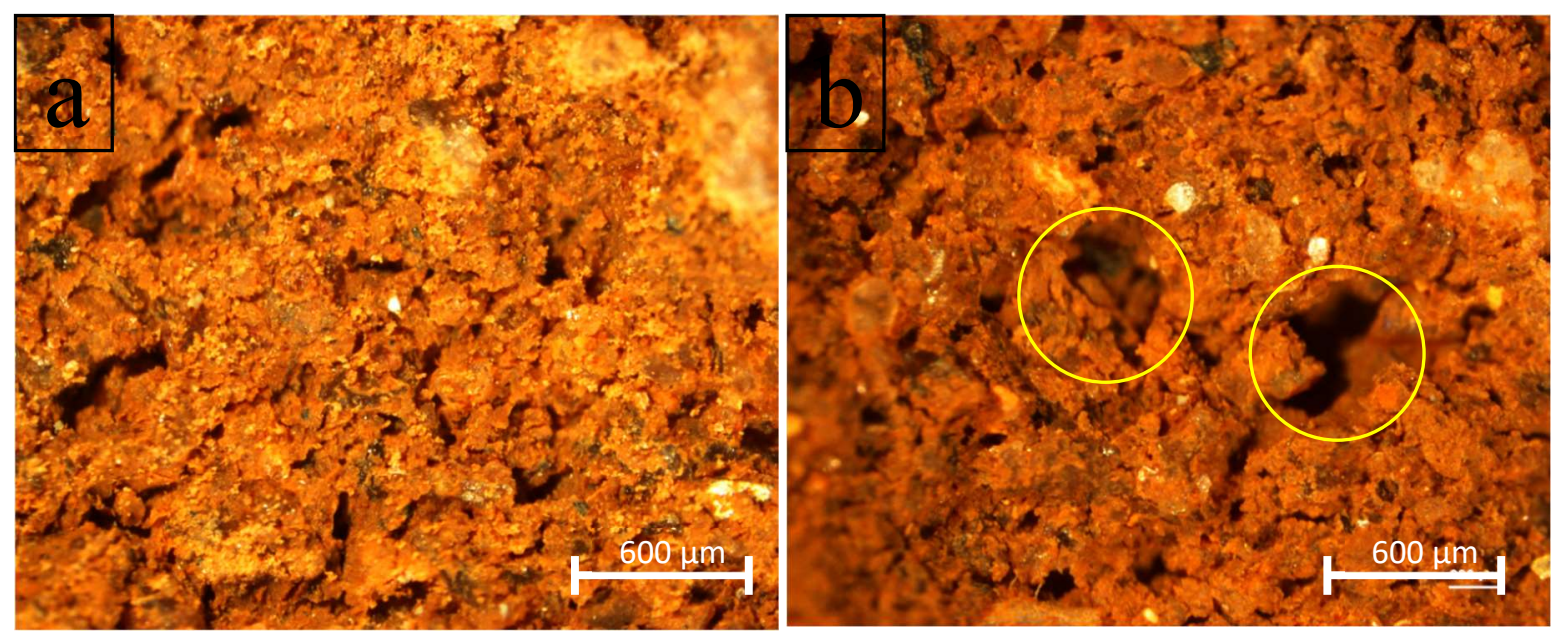

FIGURE 7. Microstructure of the adobe by stereoscopic microscopy images.

Control treatment (a); S3 treatment.

It is observed that the sample with $3 \%$ of sludge presented larger macro pores (small cracks). The pores and small cracks verified in the test demonstrate the effect of an amorphous material that was not well adhered to the crystalline matrix (soil), resulting in a lower structuring of the material, less cohesion among the clay-mineral particles, the soil and sludge and less cohesion between the clay-mineral particles and the sand.

The presence of WTP sludge in adobe promotes an increase in the bulk density. Figure 8 shows the proportion of increase due to sludge incorporation.

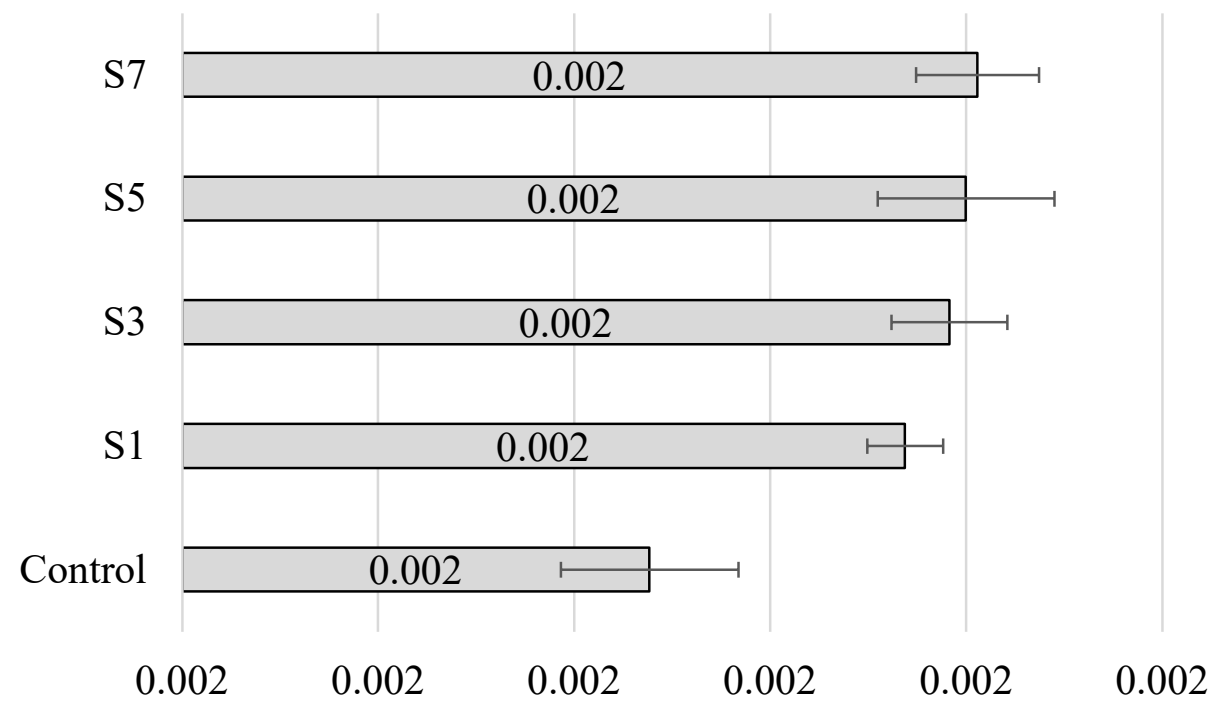

FIGURE 8. Average results for apparent density $\left(\mathrm{g} \cdot \mathrm{cm}^{-3}\right)$.

From $1 \%$ of sludge, the values of the bulk density are statistically the same. It can be stated that the increase in density is according to the largest specific mass of the sludge in relation to the soil (Table 1). The stability of the increase of the apparent density after the addition of $1 \%$ can be explained by the higher presence of cracks due to the increase of the sludge concentration, promoting the loss of mass in the drying process.

The presence of sludge when the adobe was submerged in water had a negative influence. The treatments S5 and S7 after 6 hours of submersion in water were considerably dismantled (Figure 9). 


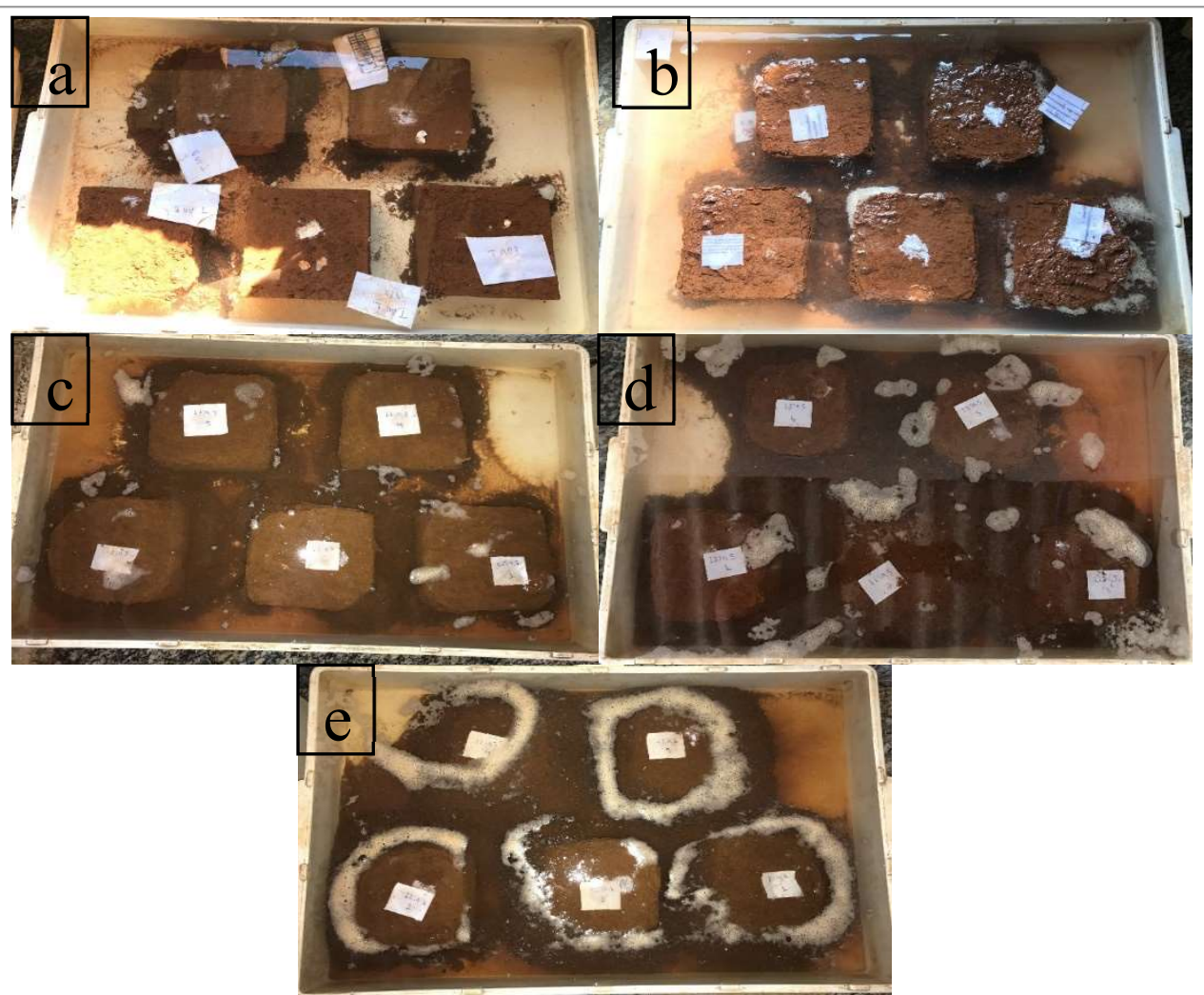

FIGURE 9. Adobes after 6 hours of submersion in water.

Control (a), S1 (b), S3 (c), S5 (d) and S7 (e).

It was not possible to calculate the value of the water absorption because the value would be negative. Despite the lower water absorption in samples S1 and S3, in relation to the control, as shown in Table 3, it can be observed that the loss of mass increased significantly with increasing sludge addition.

TABLE 3. Results of water absorption and mass loss test.

\begin{tabular}{|c|c|c|c|c|c|c|}
\hline Treatment & $\begin{array}{c}\text { Water absorption } \\
(\%)\end{array}$ & $\begin{array}{c}\text { Initial mass } \\
(\mathrm{kg})\end{array}$ & $\begin{array}{l}\text { Final mass } \\
(\mathrm{kg})\end{array}$ & Standard deviation & $\begin{array}{c}\text { Dry mass loss } \\
(\mathrm{kg})\end{array}$ & $\begin{array}{c}\text { Dry mass loss } \\
(\%)\end{array}$ \\
\hline Control & $12.03 \mathrm{a}$ & 13.120 & 14.674 & $7.64 *$ & 0.779 & 5.94 \\
\hline S1 & $7.189 \mathrm{a}$ & 13.852 & 14.614 & $3.61 *$ & 1.311 & 9.46 \\
\hline S3 & $5.957 \mathrm{a}$ & 13.736 & 14.614 & 1.64 & 1.360 & 9.90 \\
\hline S5 & $-* *$ & 13.296 & 11.081 & - & 4.002 & 30.10 \\
\hline S7 & $-* *$ & 12.480 & 8.342 & - & 5.404 & 43.30 \\
\hline Overall average & 7.11 & & & & & \\
\hline CV (\%) & 54.790 & & & & & \\
\hline
\end{tabular}

Means followed by the same letter in the same column are statistically the same by the Tukey test at $5 \%$ significance.

* One of the five samples was completely destroyed.

**Most of the samples were destroyed.

Rodrigues \& Holanda (2013), incorporating sludge in soil-cement, affirmed the increased water absorption with the addition of WTP sludge with a concomitant increase of the porosity in the bricks, and this behaviour was associated with two main effects: the increase of the fine fraction of the mixture with the increment of clay particles (mainly kaolinite) and silt; and the addition of organic matter to the soil-cement mixture. Therefore, the authors stated that the use of sludge in cement soil is limited to $1.25 \%$; above this, the material destabilizes considerably.

The incorporation of WTP sludge into concrete increased the water absorption significantly (Tafarel, 2017). According to the author, the possible increase in the water absorption in the concrete material would be due to the expansive reaction generated by the attack of sulphates, which may have caused microcracks in the sample. The author further stated that a second cause of the increased water absorption was the solubilization of the organic material and other compounds present in the sludge that were in contact with the water, which could have been drawn from the samples, forming voids within the pores that would later be filled by water during the test.

This behaviour can also be explained by the WTP sludge being an amorphous material, as shown in Figure $2 b$, so it does not show stability, and exhibits easily destructuring in contact with the pressure by the water absorbed. Therefore, the addition of WTP sludge in adobes 
is feasible up to $3 \%$, due to the lack of stability in the presence of absorbed water.

In relation to the water adsorbed by capillarity, it can be observed (Table 4 ) that with the addition of sludge in the adobe, the capillary values increased. The heights are statistically the same with the addition of WTP sludge; however, the mass loss increases with increasing sludge concentration.

TABLE 4. Average results of capillarity and mass loss.

\begin{tabular}{ccccccc}
\hline Treatment & $\begin{array}{c}\text { Water absorption } \\
(\%)\end{array}$ & $\begin{array}{c}\text { Standard deviation } \\
(\%)\end{array}$ & $\begin{array}{c}\text { Initial mass } \\
(\mathrm{kg})\end{array}$ & $\begin{array}{c}\text { Final mass } \\
(\mathrm{kg})\end{array}$ & $\begin{array}{c}\text { Dry mass loss } \\
(\mathrm{kg})\end{array}$ & $\begin{array}{c}\text { Dry mass loss } \\
(\%)\end{array}$ \\
\hline Control & $2.06 \mathrm{a}$ & 0.36 & 27.152 & 30.302 & 0.068 & 0.0025 \\
S1 & $3.03 \mathrm{~b}$ & 0.36 & 27.356 & 28.856 & 0.069 & 0.0025 \\
S3 & $3.27 \mathrm{~b}$ & 0.43 & 26.760 & 27.914 & $0.241^{*}$ & 0.0090 \\
S5 & $3.12 \mathrm{~b}$ & 0.27 & 27.304 & 28.496 & 0.145 & 0.0053 \\
S7 & $3.08 \mathrm{~b}$ & 0.92 & 25.874 & 27.090 & 0.124 & 0.0048 \\
\hline $\begin{array}{c}\text { Overall average } \\
(\%)\end{array}$ & 2.91 & & & & & \\
CV (\%) & 17.33 & & & & &
\end{tabular}

Means followed by the same letter in the same column are statistically the same by the Tukey test at $5 \%$ significance.

* One sample showed a large crack visibly before the test.

The higher level of rising water and higher mass loss may have occurred due to the expansivity of the sulphate contained in the sludge, generating micro cracks and increasing the number of pores and small paths that facilitate the movement of the water by capillarity. The increase of the mass loss can be explained by the lower cohesion between the particles, because they are an amorphous material, which have been unstructured due to the increased pressure promoted by the higher adsorption of water by capillarity.

The linear shrinkage test presented statistically the same results for all treatments. The addition of sludge to adobe did not influence the linear shrinkage. Table 5 shows the linear shrinkage values, with no significant difference at the $5 \%$ level.

TABLE 5. Results of the linear shrinkage test.

\begin{tabular}{|c|c|c|c|c|c|}
\hline \multirow{2}{*}{ Mean values } & \multicolumn{5}{|c|}{ Treatments } \\
\hline & Control & $\mathrm{S} 1$ & S3 & S5 & S7 \\
\hline Linear shrinkage $(\mathrm{cm})$ & $2.71 \mathrm{a}$ & $2.60 \mathrm{a}$ & $2.08 \mathrm{a}$ & $2.11 \mathrm{a}$ & $2.54 \mathrm{a}$ \\
\hline Linear shrinkage (\%) & 0.05 & 0.05 & 0.04 & 0.04 & 0.04 \\
\hline Standard deviation $(\mathrm{cm})$ & 0.03 & 0.50 & 0.13 & 0.05 & 0.02 \\
\hline Overall average $(\%)$ & \multicolumn{5}{|c|}{2,41} \\
\hline $\mathrm{CV}(\%)$ & \multicolumn{5}{|c|}{11,75} \\
\hline
\end{tabular}

Means followed by the same letter in the same line are statistically the same by the Tukey test at $5 \%$ significance.

Despite the non-influence on linear shrinkage, the sludge presented a greater number of fissures with the increase of its concentration, as observed in Figure 10.
Visually, the retraction was similar in all the treatments; however, there was an increase of cracks according to the increased concentration of sludge.

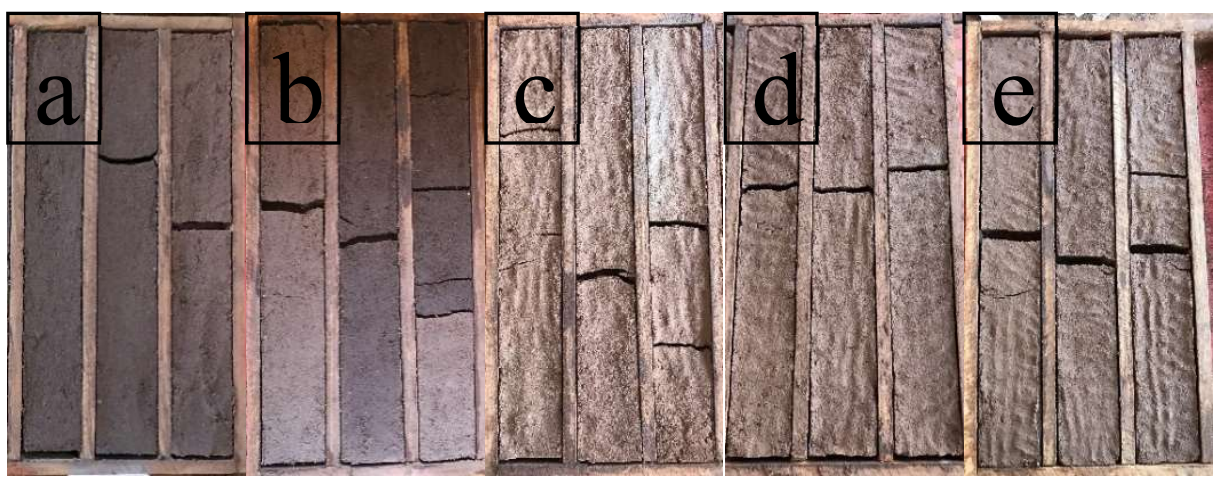

FIGURE 10. Linear shrinkage of adobes after 7 days of drying.

Control (A), S1 (B), S3 (C), S5 (D) and S7 (E). 
As shown in the microstructure (Figure 7) and confirmed by the loss of mass due to the water tests and by the stabilization of the apparent density due to the possible loss of mass by the cracks, we can say that the increase in the number of cracks in the shrinkage test is due to that the material (sludge) is amorphous, presenting a lack of structural stabilization. Another possible cause is the degradation of a small amount of organic matter, promoting empty spaces that become small and large cracks with the loss of water.

The mechanical analysis of the compressive strength showed that the use of sludge in adobes does not alter its resistance to compression. Table 6 presents the values of the compressive strength, and the average of the treatments did not show a significant difference, showing that the addition of sludge does not alter the mechanical properties of the compressive strength of the adobe.

TABLE 6. Results of the compressive strength test (MPa).

\begin{tabular}{cccc}
\hline & NTE E 080 & Brazillian & Mean value \\
\hline Control & $1.43 \mathrm{a}$ & $1.41 \mathrm{a}$ & 1.42 \\
S1 & $1.57 \mathrm{a}$ & $1.58 \mathrm{a}$ & 1.58 \\
S3 & $1.71 \mathrm{a}$ & $1.53 \mathrm{a}$ & 1.62 \\
S5 & $1.56 \mathrm{a}$ & $1.52 \mathrm{a}$ & 1.54 \\
S7 & $1.55 \mathrm{a}$ & $1.51 \mathrm{a}$ & 1.53 \\
\hline
\end{tabular}

Means followed by the same letter in the same column are statistically the same by the Tukey test at $5 \%$ significance.

The literature is scarce in terms of using WTP sludge in adobes. Works related to concrete and cement soil are presented for comparison, despite the physical and chemical differences in the material matrix.

Tafarel (2017), using WTP sludge in concrete, observed a reduction of 4.19 and $37.08 \%$ with the addition of 5 and $10 \%$ sludge respectively. It was then verified that above $5 \%$ addition of the sludge was not feasible. Rodrigues \& Holanda (2013) reported a decrease in soil-cement compression resistance using 5\% WTP sludge. The authors stated that one of the reasons is the lack of cohesion between the cement matrix and the sludge.

It is noteworthy that, although statistically equal, treatments with the addition of sludge show a small increase in the compressive strength. This fact may possibly be explained by the higher percentage of clay present in the sludge and due to the sludge clay being of the kaolinite type with cohesive and less expansive characteristics. Another factor may be the aluminium sulphate used in the WTP, presenting the power to agglutinate the soil and possibly presenting a small cohesion when the material is not exposed to and contacted with water. In addition to the granulometry of soil and sludge being similar, there is possibly a good homogenization.

The lower thermal conductivity is related to the lower energy expenditure after the construction (Millogo et al., 2016). Adobe is already considered a material with a lower energy demand compared to traditional ones (Gandia et al., 2018). Among the reasons that the adobe presents less embodied energy, the non-burning of the material and the non-use of cement are the ones that most represent this energetic reduction.

The thermal conductivity is presented in Figure 11. It was possible to affirm that the use of WTP sludge in adobes does not interfere with the passage of heat, and the values are statistically equal.

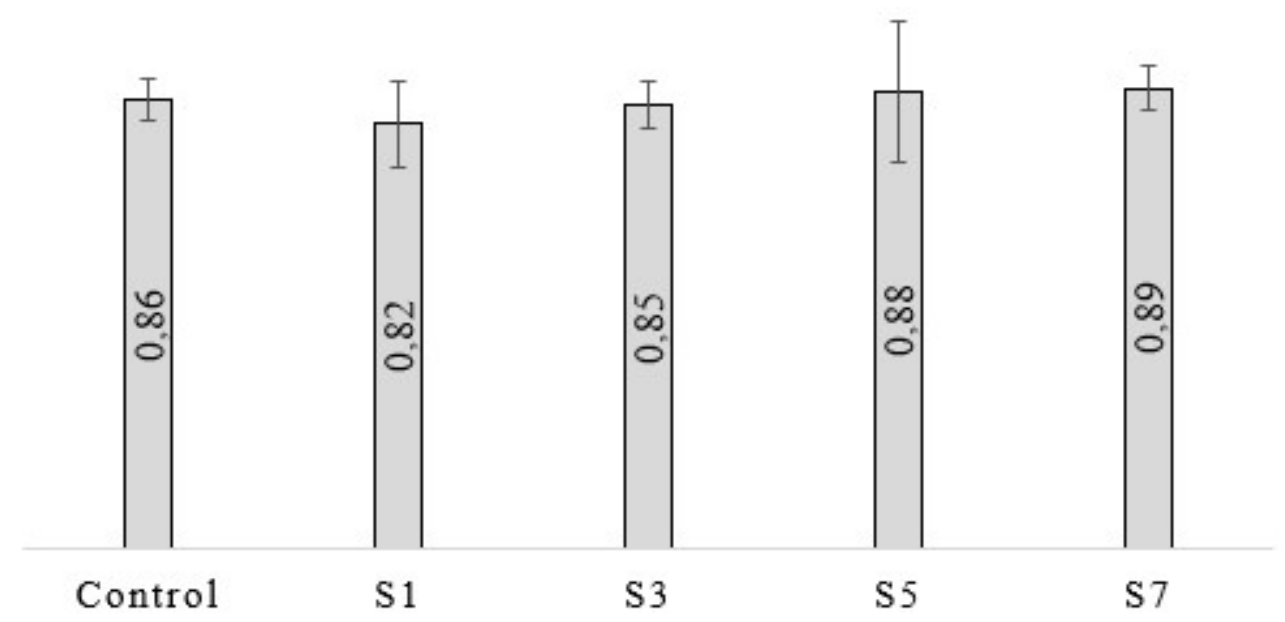

FIGURE 11. Mean values of thermal conductivity $\left(\mathrm{W} \cdot \mathrm{m}^{\circ} \mathrm{C}^{-1}\right)$. 
Mosquera et al. (2014), using two samples of adobes, i.e., one dried in a stove and another one with $1.67 \%$ humidity, found values of 0.80 and $0.90 \mathrm{~W} .\left(m^{\circ} \mathrm{C}\right)^{-1}$ respectively. The samples from the present study were stabilized at $1.5 \%$ moisture and an intermediate value of 0.86 was found.

As the evaluation of the thermal conductivity of adobe using sludge is scarce, the work of Zhang et al. (2016) using lake sediments in the production of ceramic bricks approaches the current study. In their paper, Zhang et al. (2016) found a small change in the thermal conductivity from 0.62 to $0.61 \mathrm{~W} . \mathrm{m}^{\circ} \mathrm{C}-1$. In the present study, a small change was observed but the values were statistically the same.

\section{CONCLUSIONS}

The incorporation of WTP sludge into adobes interferes in their properties. The physical analysis showed that the bulk density increased with the addition of sludge; water absorption was limited to $3 \%$ of usage, and above that, the adobe destabilized and lost a significant amount of mass; capillarity by water adsorption increased with the addition of sludge; and the linear shrinkage was not influenced by the addition of the sludge, but an increase in the number of macro cracks was observed.

The mechanical analysis of the compressive strength showed that the sludge did not interfere with the quality of the adobe by up to $7 \%$. Both methodologies used in the analysis of the compressive strength presented close and statistically equal values, and according to the norms, the values were acceptable.

As for the thermal analysis, it was observed that the sludge also had no influence on the passage of heat.

The use of sludge in adobe was feasible up to $3 \%$ in mass, maintaining its mechanical, thermal and physical properties, mainly in relation to the contact with water. Therefore, the use of WTP sludge in adobes is possible but limited, and it has an advantage in terms of sustainability. By using the residue correctly and do not returning it to the site of abstraction, contamination problems can be avoided.

\section{REFERENCES}

Ahmad T, Ahmad K, Alam M (2016) Sustainable management of water treatment sludge through 3 ' $R$ ' concept. Journal of Cleaner Production 124:1-13. DOI: https://doi.org/10.1016/j.jclepro.2016.02.073

ABNT - Associação Brasileira de Normas Técnicas (1981) NBR-7180. Solo - Determinação do limite de plasticidade. Método de Ensaio. ABNT, 3p.

ABNT - Associação Brasileira de Normas Técnicas (1982) NBR-7183. Determinação do limite e relação de contração dos solo. Método de ensaio. ABNT, 3p.

ABNT - Associação Brasileira de Normas Técnicas (1984) NBR-7181. Análise granulométrica. Método de Ensaio. ABNT, 13p.

ABNT - Associação Brasileira de Normas Técnicas (1986) NBR-9776. Agregados - Determinação da massa específica de agregados miúdos por meio do frasco Chapman. Método de Ensaio. ABNT, 3p.
ABNT - Associação Brasileira de Normas Técnicas (2004a) NBR 10004. Resíduos sólidos - classificação. ABNT, 6p.

ABNT - Associação Brasileira de Normas Técnicas (2004b) NBR 10005. Procedimento para obtenção de extrato lixiviado de resíduos sólido. ABNT, 20p.

ABNT - Associação Brasileira de Normas Técnicas (2004c) NBR-6459. Determinação do limite de liquidez. Método de ensaio. ABNT, 6p.

Aguilar R, Nakamatsu J, Ramírez E, Elgegren M, Kim S, Pando MA, San Martin LO (2016) The potential use of chitosan as a biopolymer additive for enhanced mechanical properties and water resistance of earthen construction. Construction and Building Materials 114:625-637. DOI: https://doi.org/10.1016/j.conbuildmat.2016.03.218

AWWA - American Water Works Association (1996) American society of civil engineers. New York, American Society of Civil Engineers, 294p.

Balkis AP (2017) The effects of waste marble dust and polypropylene fiber contents on mechanical properties of gypsum stabilized earthen. Construction and Building Materials 134:556-562. DOI:

https://doi.org/10.1016/j.conbuildmat.2016.12.172

Barbosa NP, Ghavami K (2007) Materiais de construção civil e princípios de ciência e engenharia de materiais. In Isaia GC (org). Terra crua. Ibracon 2:1505-1557.

BNH - Banco Nacional da Habitação (1985)

Uniformização das técnicas de aplicação do solo-cimento na construção habitacional. DEPEA/BNH, 14 p.

CEPED - Centro de Pesquisas e Desenvolvimento (1984) Manual de construção com solo-cimento. 3 ed.atual. CEPED/ BNH/ URBIS/ CONDER/ PMC/OEA/ CEBRACE/ ABCP, $147 \mathrm{p}$.

Corrêa AAR, Teixeira VH, Lopes SP, Oliveira MS (2006) Evaluation of physical and mechanical properties of adobe bricks. Ciência e Agrotecnologia 30(3):503-515. DOI: http://dx.doi.org/10.1590/S1413-70542006000300017

Corrêa AAR, Mendes LM, Barbosa NP, Protássio TP, Campos NA, Tonoli GHD (2015) Incorporation of bamboo particles and "synthetic termite saliva" in adobes. Construction and Building Materials 98:250-256. DOI: https://doi.org/10.1016/j.conbuildmat.2015.06.009

DNER - Departamento Nacional de Estradas de Rodagem. ME 138 (1994) Pavimentos flexíveis - Misturas betuminosas - determinação da resistência à tração por compressão diametral. Rio de Janeiro, DNER. Available: http://www1.dnit.gov.br/normas/Determinacao $\% 20 \mathrm{da} \% 20$ Resistencia\%20a\%20Tracao\%2 0\%20VERSAO\%20DEFINITIVA.pdf. Accessed: Apr 21, 2016.

Danso H, Martinson B, Ali M, Williams JB (2015) Physical, mechanical and durability properties of soil building blocks reinforced with natural fibres. Construction and Building Materials 101:797-809. DOI: https://doi.org/10.1016/j.conbuildmat.2015.10.069 
Di Bernardo L, Dantas ADB, Voltan PEN (2012) Métodos e técnicas de tratamento e disposição dos resíduos gerados em Estações de Tratamento de Água. São Carlos, 480p.

Dove CA, Bradley FF, Patwardhan SV (2016) Seaweed biopolymers as additives for unfired clay bricks. Materials and Structures 49(11):4463-4482. DOI:

https://doi.org/10.1617/s11527-016-0801-0

Eires R, Camôes A, Jalali S (2017) Enhancing water resistance of earthen buildings with quicklime and oil. Journal of Cleaner Production 142:3281-3292. DOI: https://doi.org/10.1016/j.jclepro.2016.10.141

Faria OB (2002) Utilização de macrófitas aquáticas na produção de adobe: um estudo no reservatório de Salto Grande. Tese Doutorado, São Carlos, Universidade de São Paulo, Escola de Engenharia de São Carlos.

Ferreira Filho SS, Waelkens BE (2009) Minimização da produção de lodo no tratamento de águas de abastecimento mediante uso do cloreto de polialumínio e sua disposição em estações de tratamento de esgotos. Engenharia Sanitária e Ambiental 14(3):317-326. DOI: https://doi.org/10.1590/S1413-41522009000300005

Ferreira DF (2011) Sisvar: um sistema de análise estatística computador. Ciência e Agrotecnologia 35:1039-1042.

Fonollosa E, Nieto A, Peñalver C, Borrull F (2015) Presence of radionuclides in sludge from conventional drinking water treatment plants. Journal of Environmental Radioactivity 141:24-31. DOI:

https://doi.org/10.1016/j.jenvrad.2014.11.017

Galán-Marín C, Rivera-Gómez C, Petric J (2010) Claybased composite stabilized with natural polymer and fiber. Construction and Building Materials 24(8):1462-1468. DOI: https://doi.org/10.1016/j.conbuildmat.2010.01.008.

Gandia RM, Campos AT, Corrêa AAR, Gomes FC (2018) Energy costs comparison of masonry made from different materials. Theoretical and Applied Engineering 2(1):1-8. DOI: https://doi.org/10.31422/taae.v2i1.2.

Gandia RM, Corrêa AAR, Gomes FC, Marin DB, Santana LS (2019) Physical, mechanical and thermal behavior of adobe stabilized with" synthetic termite saliva". Engenharia Agrícola 39(2):139-149. DOI: http://dx.doi.org/10.1590/1809-4430eng.agric.v39n2p139-149/2019

Gastaldini ALG, Hengen MF, Gastraldini MCC, Amaral FD, Antolini MB, Coletto T (2015) The use of water treatment plant sludge ash as a mineral addition. Construction and building materials 94:513-520. DOI: https://doi.org/10.1016/j.conbuildmat.2015.07.038

González-Corrochano B, Alonso-Azcárate J, Rodriguez L, Lorenzo AP, Torío MF, Ramos JJT, Corvinos MD, Muro C (2016) Valorization of washing aggregate sludge and sewage sludge for lightweight aggregates production. Construction and Building Materials 116:252262. DOI: https://doi.org/10.1016/j.conbuildmat.2016.04.095

Hamard E, Cazacliu B, Razakamanantsoa A, Morel JC (2016) Cob, a vernacular earth construction process in the context of modern sustainable building. Building and Environment 106:103-119. DOI:

https://doi.org/10.1016/j.buildenv.2016.06.009
Hoppen C, Portealla KF, Joukoski A, Trindade EM, Andreóli C (2006) Uso de lodo de estação de tratamento de água centrifugado em matriz de concreto de cimento portland para reduzir o impacto ambiental. Química Nova 29(1):79-84.

Huang CH, Wang SY (2013) Application of water treatment sludge in the manufacturing of lightweight aggregate. Construction and Building Materials 43:174183. DOI: https://doi.org/10.1016/j.conbuildmat.2013.02.016.

Kizinievič O, Žurauskienè R, Kizinievič V, Žurauskas R (2013) Utilisation of sludge waste from water treatment for ceramic products. Construction and Building Materials 41:464-473. DOI:

https://doi.org/10.1016/j.conbuildmat.2012.12.041.

Laborel-Préneron A, Aubert JE, Magniont C, Tribout C, Bertron A (2016) Plant aggregates and fibers in earth construction materials: A review. Construction and Building Materials 111:719-734. DOI: https://doi.org/10.1016/j.conbuildmat.2016.02.119.

Lima JM, Tavares G (2008) Processo automatizado com controle de vazão para reuso de efluentes de filtros de estação e tratamento de água. Brasil.

Patente 0802791,9 Fev 2009.

Lucena CL, Juca JFT, Soares JB, Barroso SHA, Portela MG (2016) Characterization and evaluation of the potential use of sludge from STP and WTP in Paving. Engenharia Agrícola 36(1):166-178.

Martínez-García C, Eliche-Quesada D, Pérez-Villarejo L, Iglesias-Godino FJ, Corpas-Iglesias FA (2012) Sludge valorization from wastewater treatment plant to its application on the ceramic industry. Journal of environmental management 95:343-348. DOI: https://doi.org/10.1016/j.jenvman.2011.06.016

Millogo Y, Morel JC, Aubert JE, Ghavami K (2014) Experimental analysis of pressed adobe blocks reinforced with Hibiscus cannabinus fibres. Construction and Building Materials 52:71-78. DOI:

https://doi.org/10.1016/j.conbuildmat.2013.10.094

Millogo Y, Aubert JE, Séré AD, Fabbri A, Morel JC (2016) Earth blocks stabilized by cow-dung. Materials and Structures 49(11):4583-4594. DOI:

https://doi.org/10.1617/s1152

Nakamatsu J, Kim S, Ayarza J, Ramírez E, Elgegren M, Aguilar A (2017) Eco-friendly modification of earthen construction with carrageenan: Water durability and mechanical assessment. Construction and Building Materials 139:193-202. DOI:

https://doi.org/10.1016/j.conbuildmat.2017.02.062

NTE - Norma Técnica de Edficación (2000) NTE.E-080: regulamento nacional de construcciones. NTE, $17 \mathrm{p}$.

Pacheco-Torgal F, Jalali S (2012) Earth construction: Lessons from the past for future eco-efficient construction. Construction and building materials 29:512519. DOI: https://doi.org/10.1016/j.conbuildmat.2011.10.054 
Palme M, Guerra J, Alfaro S (2014) Thermal performance of traditional and new concept houses in the ancient village of San Pedro de Atacama and surroundings. Sustainability 6(6):3321-3337. DOI: https://doi.org/10.3390/su6063321

Ramirez KG, Possan E, Dezen BGS, Colombo M (2017) Potential uses of waste sludge in concrete production. Management of Environmental Quality: An International Journal 28(6):821-838. DOI: https://doi.org/10.1108/MEQ-09-2015-0178

Richter CA (2001) Tratamento de lodos de estações de tratamento de água. São Paulo, Edgard Blucher, 112 p.

Rodrigues FN (2015) Caracterização dos resíduos da estação de tratamento de água da UFLA e aproveitamento na confecção de tijolos de solo-cimento. Dissertação Mestrado, Lavras, Universidade Federal de Lavras.

Rodrigues LP, Holanda JNF (2013) Influência da incorporação de lodo de estação de tratamento de água (ETA) nas propriedades tecnológicas de tijolos solocimento. Cerâmica 59(352):551-556. DOI: https://doi.org/10.1590/S0366-69132013000400010

Ruiz LEH, Luna JAM (1983) Cartilha de pruebas de campo. Conescal, $72 \mathrm{p}$.

Silva AR (2010) Estudo térmico e de materiais de um bloco para construção de casas populares, confeccionado a partir de um compósito a base de gesso, EPS e raspa de pneu. Tese, Natal, Universidade Federal do Rio Grande do Norte.

Sanepar (2014) Sistema corporativo de controle industrial. Foz do Iguaçu, Sanepar.
Embrapa (2013) Solos. Sistema brasileiro de classificação de solos. Rio de Janeiro, Centro Nacional de Pesquisa de Solos.

Stazi F, Nacci A, Tittarelli F, Pasqualini E, Munafò P (2016) An experimental study on earth plasters for earthen building protection: The effects of different admixtures and surface treatments. Journal of Cultural Heritage 17:2741. DOI: https://doi.org/10.1016/j.culher.2015.07.009.

Tafarel NF, Macioski G, Carvalho KQ, Nagalli A, Freitas DC, Passig FH (2016) Evaluation of concrete properties due to the incorporation of sludge from Water Treatment Plant. Matéria 21(4):974-986. DOI: http://dx.doi.org/10.1590/s1517-707620160004.0090

Tao J, Wu S, Sun L, Tan X, Yu S, Zhang Z (2012) Comosition of waste sludge from municipal wastewater treatment plant. Procedia Environmental Sciences 12:964971. DOI: https://doi.org/10.1016/j.proenv.2012.01.372

Teixeira SR, Santos GTA, Souza AE, Alessio P, Souza AS, Souza NR (2011) The effect of incorporation of a Brazilian water treatment plant sludge on the properties of ceramic materials. Applied Clay Science 53(4):561-565, 2011. DOI: https://doi.org/10.1016/j.clay.2011.05.004

Varum H, Costa A, Silveira D, Carvalho G, Silva L (2007) Caracterização dos solos e adobes usados na construção los Camabatelas, Angola. Aveiro, Argumentum p 94-96.

Zhang YM, Jia LT, Mei H, Cui Q, Zhang PG, Sun Zm (2016) Fabrication, microstructure and properties of bricks fired from lake sediment, cinder and sewage sludge. Construction and Building Materials 121:154-160. DOI: https://doi.org/10.1016/j.conbuildmat.2016.05.155 


\section{ERRATUM}

In the paper "PHYSICAL, MECHANICAL AND THERMAL BEHAVIOUR OF ADOBE STABILIZED WITH THE SLUDGE OF WASTEWATER TREATMENT PLANTS", with DOI number: 10.1590/1809-4430-Eng.Agric.v39n6p684-697/2019, published in the journal Agricultural Engineering 39 (6):684-697, on the page 691:

Where it reads:

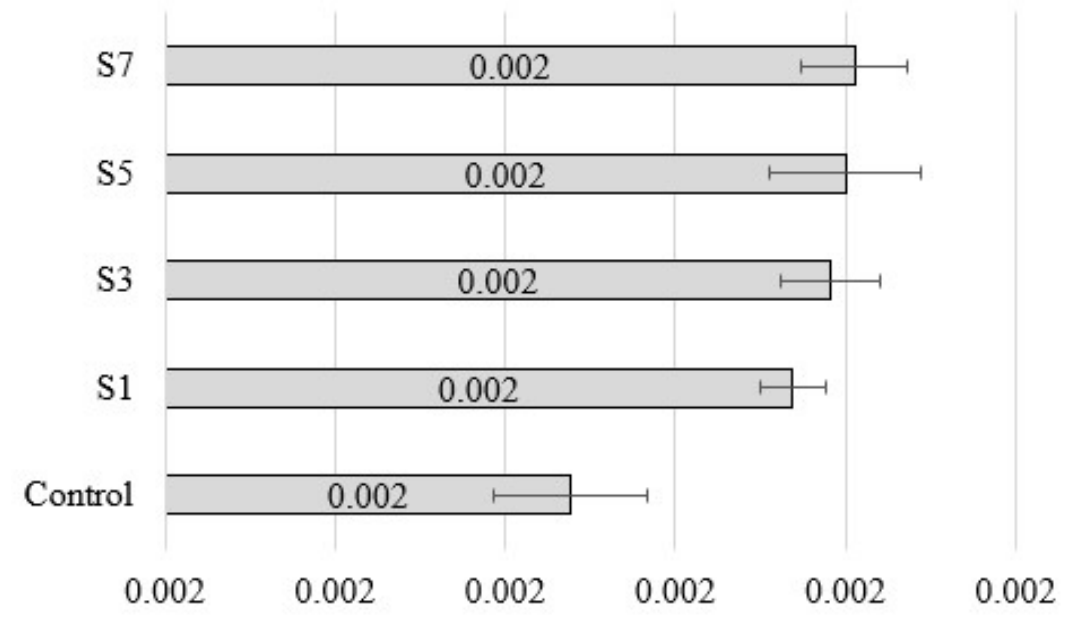

FIGURE 8. Average results for apparent density $\left(\mathrm{g} \cdot \mathrm{cm}^{-3}\right)$.

It should read:

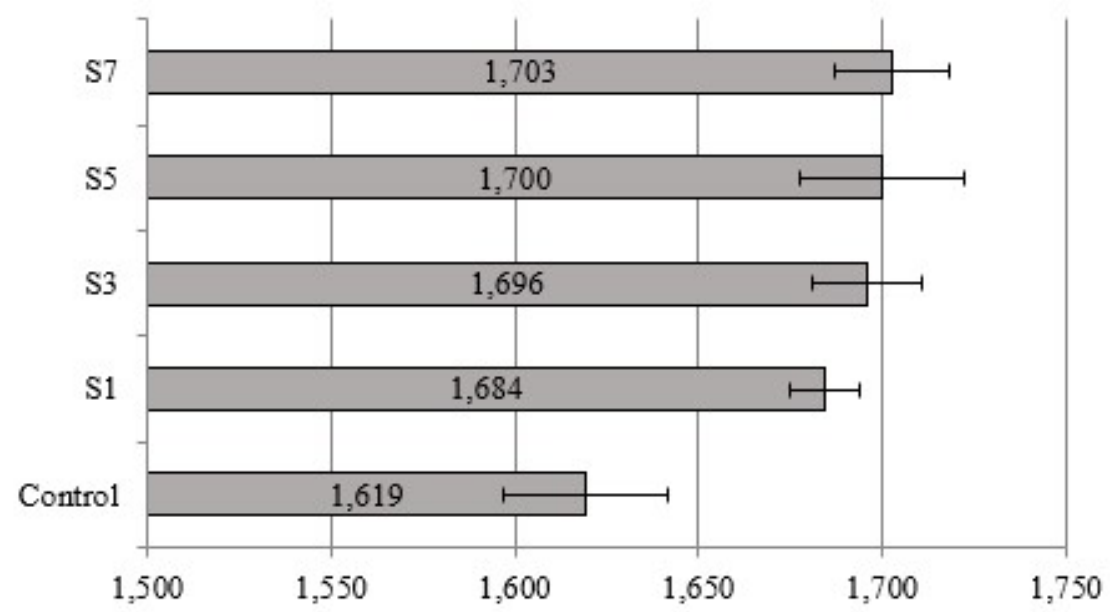

FIGURE 8. Average results for bulk density $\left(\mathrm{g} \cdot \mathrm{cm}^{-3}\right)$. 